\title{
CLINICAL CHARACTERISATION OF ROTA VIRUS INFECTION ASSOCIATED WITH MOST COMMONLY CIRCULATING GENOTYPES IN CHILDREN HOSPITALISED IN CHILDREN'S UNIVERSITY HOSPITAL: A CROSS-SECTIONAL STUDY IN LATVIA
}

Gunta Laizāne ${ }^{1,2, \#}$, Anda Kīvìte ${ }^{3}$, Ilze Grope ${ }^{1}$, Liene Smane ${ }^{1,2}$, Edvīns Miklaševics ${ }^{4,5}$, Laura Ozolina ${ }^{4}$, and Dace Gardovska ${ }^{1,2}$

\footnotetext{
${ }^{1}$ Department of Paediatrics, Rīga Stradinš University, 45 Vienības Av., Rīga, LV-1004, LATVIA

${ }^{2}$ Children's Clinical University Hospital, 45 Vienības Av., Rīga, LV-1004, LATVIA

${ }^{3}$ Department of Public Health and Epidemiology, Rīga Stradiṇš University, 9 Kronvalda Blvd., Rīga, LV-1010, LATVIA

${ }^{4}$ Department of Biology and Microbiology, Rīga Stradiṇš University, 16 Dzirciema Str., Rīga, LV-1007, LATVIA

${ }^{5}$ Institute of Oncology, Pauls Stradinš Clinical University Hospital, 13 Pilsoṇu Str., Rīga, LV -1002, LATVIA

\# Corresponding author, Igunta@inbox.Iv
}

Contributed by Dace Gardovska

\begin{abstract}
In developed and developing countries, most cases of acute gastroenteritis in children are caused by viruses, and rotaviruses are known as the leading cause. The aim of our study was to estimate the main circulating serotypes of rotavirus before the introduction of routine immunisation in Latvia, and to search for their possible correlation with clinical symptoms and circulating genotypes. A cross-sectional study was carried out among children who had been hospitalised in the Children's Clinical University Hospital from April 2013 to December 2015. Genotyping was done for 462 stool samples. Among G/P combinations, the most predominant genotypes were G4P[8] (61.3\%), G9P[8] (12.4\%) and G2P[4] (10.0\%) in children of age < 5 years, G4P[8] (45.5\%), G2P [4] (18.2\%), G9P[8], G3P[8], and G1P[8] (9.1\%) in children of age > 5 years. There was a statistically significant correlation $(\mathrm{p}<0.05)$ between clinical signs (vomiting, dehydration, chronic diseases) and G1P[8] and G8P[8] genotypes. Infants infected with genotype G4P[4] had a statistically significant negative correlation with severity of acute gastroenteritis episodes $(\mathrm{p}<0.05)$. We detected nine different rotavirus $G$ genotypes, and two different $P$ genotypes. G4P[8], G9P[8], and G2P[8] were predominant. We observed correlation between the dominant genotypes and clinical manifestations of rotavirus infection.
\end{abstract}

Key words: rotavirus, gastroenteritis, genotyping, children, clinical characterisation.

\section{INTRODUCTION}

In developed and developing countries, most cases of acute gastroenteritis in children are caused by viruses. Rotaviruses are known as the leading cause of severe gastroenteritis among infants and children up to age of five worldwide (Parashar et al., 2013). Rotaviruses were the most important causative agents of acute gastroenteritis in young children, until universal rotavirus vaccination was introduced in many countries (Cortese et al., 2010; Curns et al 2010; Buttery et al., 2011). Gastroenteritis caused by rotavirus is fre- quently associated with severe disease symptoms (vomiting, diarrhea, dehydration, etc.) that lead to increased numbers of hospitalisation cases, compared to other types of acute gastroenteritis (Gimenez-Sanchez et al., 2010). From 2010 to 2015 , about 3000 rotavirus cases per year were reported in the age group of 0-6 years, leading to almost 1000 hospitalisations per year in Latvia (see https://www.spkc.gov.lv/en).

Rotavirus is the most common viral cause of severe diarrhea in infants and young children worldwide (Parashar et al 
2009). These viruses belong to the Reoviridae virus family. Its genome consists of 11 segments of double stranded RNA enclosed in a triple layered capsid (Estes et al., 1996). The outer layer of a rotavirus is composed of two proteins, VP7 and VP4, encoded by RNA segments 9 and 4. The current classification of grouping of rotaviruses into G (VP7) and $\mathrm{P}$ (VP4) types was developed based on these proteins. $\mathrm{G}$ stands for glycoprotein and $\mathrm{P}$ for protease sensitive protein (Estes et al., 1986). A combined typing system is necessary to characterise circulation of different serotypes in different seasons and localisations. P[8], P[4] and G1 to G4 and G9 are the most common P- and G-types found in humans globally. Limited combinations of $\mathrm{G}$ and $\mathrm{P}$ genotypes are common in humans. G1P[8], G2P[4], G3P[8], G4P[8], and G9P [8], are the most prevalent rotavirus types detected in most studies (Gentsch et al., 1996; Seo et al., 2000).

The aim of this study was to estimate the main circulating serotypes of rotavirus before the introduction of routine immunisation in Latvia, and to search for their possible correlation with clinical symptoms and severity of disease.

\section{MATERIALS AND METHODS}

Study design. To determine the circulating serotypes and severity of Rotavirus gastroenteritis in hospitalised children, a cross-sectional study was carried out among children who had been hospitalised in the Children's Clinical University Hospital from April 2013 to December 2015 in Rìga.

Inclusion and exclusion criteria. The study comprises cases of rotavirus-positive hospitalised children ( $0-18$ years of age). Cases were excluded if there was an absence of parents or legal representatives or they were not willing to participate and provide a written consent.

Ethics approval and consent to participate and data publication. The study consent and protocol were approved by the ethical committee of Rīga Stradiňš University and by the Institutional Review Board of Children's Clinical University Hospital. The study was conducted in accordance with the Helsinki declaration and good clinical practice guidelines.

All involved parents or patients' legal representatives signed a participation consent and written informed consent was obtained from the parents for the analysis and publication of collected data.

Data collection. Parents of laboratory confirmed rotaviruspositive children were invited to participate in the study. Data regarding the clinical status of the child were obtained from patient clinical records and all results were collated in a questionnaire. A faecal sample was taken from each participant for further serotype detection, and the result was added to the questionnaire.

Instruments used. A questionnaire was developed to obtain data from rotavirus-affected children.
The questionnaire contained a clinical part with questions regarding demographic data of the patient and family, as well as objective and subjective signs and symptoms for determination of the severity of the case. Data were filled-in by the medical staff. To categorise clinical severity, the Vesikari score (Vesikari et al., 2011) was used.

Five-hundred twenty-seven hospitalised RotaStrip®-positive subjects were enrolled in the study from April 2013 to December 2015. A single stool sample was taken from each subject for serotype detection. Samples were stored at $-20{ }^{\circ} \mathrm{C}$. 497 stool samples were determined to be suitable, and genotyping was done for 462 samples.

RNA extraction. Faecal specimens were diluted $1: 10$ in phosphate-buffered saline. After thorough mixing, each faecal suspension was centrifuged for 20 minutes at $1000 \mathrm{~g}, 4$ C. RV ds RNA was extracted from $140 \mathrm{~mL}$ of $10 \%$ faecal suspensions using a RNA extraction Kit (QIAamp Viral RNA mini Kit (spin protocol); Qiagen, Inc., Hilden, Germany) in accordance with the manufacturer's instructions.

Reverse transcription-polymerase chain reaction. $G$ and $\mathrm{P}$ genotyping was performed using reverse transcriptionpolymerase chain reaction (RT-PCR) and Sanger sequencing. RT-PCR was performed using a GoTaq 1-Step-RT-qPCR System (Promega, Madison, Wisconsin, USA). Genotyping was done using a primer set for rotavirus genotyping VP4 and VP7 genotypes. It was performed using the following oligonucleotide primer pairs: VP4-F 5?-TAT GCT CCA GTN AAT TGG-3', VP4-R 5'-ATT GCA TTT CTT TCC ATA ATG-3', VP7-F 5'-ATG TAT GGT ATT GAA TAT ACC AC-3' and VP7-R 5'-AAC TTG CCA CCA TTT TTT CC-3' (Gouvea et al., 2012., Ushijima et al., 1992). Thermal cycling for the VP4 region was $95{ }^{\circ} \mathrm{C}$ for $10 \mathrm{~min}, 35$ cycles of $\left(94{ }^{\circ} \mathrm{C}\right.$ for $1 \mathrm{~min}, 50{ }^{\circ} \mathrm{C}$ for $1 \mathrm{~min}, 72{ }^{\circ} \mathrm{C}$ for $1 \mathrm{~min}$ ), then $72^{\circ} \mathrm{C}$ for $10 \mathrm{~min}$. Thermal cycling for the VP7 region was $95^{\circ} \mathrm{C}$ for $10 \mathrm{~min}, 40$ cycles of $\left(94{ }^{\circ} \mathrm{C}\right.$ for $1 \mathrm{~min}$, gradient from $45{ }^{\circ} \mathrm{C}$ to $65{ }^{\circ} \mathrm{C}$ for 45 sec, $72{ }^{\circ} \mathrm{C}$ for $1 \mathrm{~min}$ ), then $72{ }^{\circ} \mathrm{C}$ for $10 \mathrm{~min}$. Amplified products were $663 \mathrm{bp}$ for VP4 gene and $880 \mathrm{bp}$ for VP7 gene (Aly et al., 2015).

Nucleotide sequencing and sequence analysis. PCR products were purified using a MinElute 96UF PCR Purification Kit (Qiagen, Hilden, Germany) in accordance with the manufacturer's instructions. The concentration of the purified DNA samples was determined using a NanoDrop ND1000 Spectrophotometer.

The sequencing reaction was performed using an $\mathrm{ABI}$ PRISM BigDye terminator cycle sequencing reaction kit (Applied Biosystems, Foster City, CA, USA). Thermal cycling was $96{ }^{\circ} \mathrm{C}$ for $1 \mathrm{~min}, 40$ cycles of: $96^{\circ} \mathrm{C}$ for $10 \mathrm{~min}$, $50{ }^{\circ} \mathrm{C}$ for $5 \mathrm{sec}, 60{ }^{\circ} \mathrm{C}$ for $4 \mathrm{~min}$. Sequence data were collected by means of an automated DNA analyser Applied Biosystems (ABI) Prism 3130 Genetic Analyzer (Life Technologies, Foster City, California, USA). 
Data analysis was performed using the National Centre for Biotechnology Information (NCBI) Basic Local Alignment Tool (BLAST).

In the period from 2013-2015, 3301 hospitalisation cases were recorded as related to Rotavirus gastroenteritis. All enrolled patients were rotavirus-positive, and the study did not have a rotavirus negative control group.

Statistical analysis. To characterise the studied group in general, conventional descriptive statistical methods were used. Spearman's correlation coefficient $|\mathrm{r}|$ was calculated using range scale values. Data processing was performed using IBM SPSS Statistics (Statistical Package for the Social Science, Version 22.0).

\section{RESULTS}

A total of 527 stool samples were collected from children aged 18 years. 497 stool samples were confirmed as suitable, and genotyping was done for 462 samples.

Rotavirus and demographic data: Rotavirus was detected more often $(50.6 \%$ subjects) in boys than in girls $(49.4 \%$ subjects). The children with gastroenteritis were aged 1 to 209 months. The median age of the 462 children was 26.2 months. The age group analysis of rotavirus-positive cases revealed that the highest infection rate $(92.9 \%$ prevalence) was among children less than 60 months of age. Children till 24 months of age were the most affected (61.0\%). According to the seasonal distribution, it was observed that rotavirus infection was detected throughout the year but the relative frequency of rotavirus gastroenteritis was highest in winter. The seasonal distribution of rotavirus infection was as follows: $27.8 \%(\mathrm{n}=128)$ in spring, $16.9 \%(\mathrm{n}=78)$ in summer, $17.7 \%(\mathrm{n}=82)$ in autumn and $37.6 \%(\mathrm{n}=174)$ in winter. The highest number of detection rotavirus gastroenteritis cases was found in March $(\mathrm{n}=81)$ and the lowest in December $(\mathrm{n}=11)$.

Rotavirus genotyping. Genotyping was performed on 462 rotavirus positive stool samples by using reverse transcription-polymerase chain reaction (RT-PCR) and Sanger sequencing. In single-type infections, the predominant G/P combinations were G1P[8], G2P[4], G2P[8], G3P[8], G4P[8], G9P[8], G8P[8], G1P[4], and G4P[4], which respectively accounted for $30(6.5 \%), 49(10.6 \%), 12(2.6 \%)$, 19 (4.1\%), 278 (60.2\%), 56 (12.1\%), $16(3.5 \%), 1(0.2 \%)$ and $1(0,2 \%)$ of cases (Table 1$)$. Among G/P combinations, the most predominant genotypes were G4P [8] $(61.3 \%, \mathrm{n}=$ 263), G9P[8] $(12.4 \%, \mathrm{n}=53)$ and G2P[4] $(10.0 \%, \mathrm{n}=43)$ in children aged $<5$ years, G4P[8] $(45.5 \%, \mathrm{n}=15)$, G2P[4] $(18.2 \%, n=6)$, G9P[8], G3P[8], and G1P[8] (9.1\%, n = 3) in children aged 5 years. The most predominant genotypes were G4P[8] $(41.5 \%, \mathrm{n}=34)$ and G9P[8] $(42.7 \%, \mathrm{n}=35)$ in infants, G4P[8] at 13-24 months (61.2 \%, $\mathrm{n}=180), \mathrm{G} 4 \mathrm{P}[8]$ at 25-36 months $(74.4 \%, \mathrm{n}=64)$, and G4P[8] at $\geq 37$ months $(60.2 \%, \mathrm{n}=278)$. G1P[4] was identified only in infants, while G4P[4] at 13-24 months of age.

For G/P combinations, we compared all major G/P combinations with clinical manifestations. Children $(n=30)$ infected with G1P[8] and children $(n=16)$ infected with G8P [8] genotype presented with more vomiting episodes in 24 hours $(\mathrm{r}=0.104 ; p<0.05)$ than those infected with other $\mathrm{G}$ genotypes. Children with G1P[8] genotype had statistically significant positive correlation with chronic diseases $(\mathrm{r}=$ $0.155 ; p<0.05)$.

Children with the G8P[8] genotype had statistically significant positive correlation with dehydration signs, febrile temperature and vomiting episodes $(\mathrm{r}=0.167 ; \mathrm{r}=0.142 ; \mathrm{r}=$ 0.104; $p<0.05$ ), while children with the G3P[8] genotype had statistically significant positive correlation with durations of diarrhea $(r=0.150 ; p<0.001)$ and statistically significant negative correlation with vomiting and febrile temperature episodes $(\mathrm{r}=-0.099 ; \mathrm{r}=-0,092 ; p<0.05)$. It should be noted that infants infected with genotype G4P[4] had statistically significant negative correlation with severity of acute gastroenteritis episodes $(r=-0.104 ; p<0.05)$ and statistically significant positive correlation with vaccination status $(\mathrm{r}=0.108 ; p<0.05)$, while $\mathrm{G} 4 \mathrm{P}[8]$ had statistically significant negative correlation with dehydration signs $(\mathrm{r}=-0.107 ; p<0.05)$.

However, there were no statistically significant correlations between clinical manifestations and genotypes G2P[4], G2P[8], G9P[8], and G1P[4].

\section{DISCUSSION}

This study on the molecular epidemiology of rotaviruses circulating in Latvia is the first long-term systematic study of rotavirus strain diversity. The aim of this study was to estimate the main circulating serotypes of rotavirus before introduction of routine immunisation in Latvia, and to search for their possible correlations with clinical symptoms and severity of disease.

The present study found that the most common rotavirus genotypes affecting children were G1, G2, G3, G4 and G9, associated with genotypes $\mathrm{P}[4]$ and $\mathrm{P}[8]$ in stool samples

Table 1

DISTRIBUTION AND RELATIVE FREQUENCIES OF VARIOUS COMBINATIONS OF G- AND P-GENOTYPES

\begin{tabular}{l|c|c|c|c|c|c}
\hline \multirow{2}{*}{ P genotypes } & \multicolumn{7}{c}{ G Genotypes } & \\
\cline { 2 - 7 } & G1 & G2 & G3 & G4 & G8 & G9 \\
\hline $\mathrm{P}[4]$ & $1(0.2 \%)$ & $49(10.6 \%)$ & $1(0.2 \%)$ & & $56(12.1 \%)$
\end{tabular}


collected in Latvia in the season 2013/2015. In this study, a high prevalence of the G4P (Estes et al., 1996) genotype was determined to be the cause of childhood gastroenteritis. These results differ from the studies by Soeorget al. (2012), which found that the most frequent strain in Estonia was G2P[4] in the 2007/2008. Piekarska et al. (2015) found that predominant genotype in rotavirus gastroenteritis in Polish children was G3P[9] in 2010 . In Italy G1P[8] and G9P[8] rotavirus gastroenteritis strains were detected frequently, whereas G12P[8] caused a single large nosocomial outbreak (Ianiro et al., 2017). So far, it has been reported that the most common rotavirus genotypes affecting humans were G1, G2, G3, G4 and G9, associated with genotypes P[4] and $\mathrm{P}[8]$; the genotypes G1, G2, G3 and G4 were observed in 90-95\% of cases in Europe. Van Damme et al. investigated the distribution of rotavirus genotypes in well-defined areas of seven European countries. In that study, five main genotypes (G1-G4 and G9) were found, which accounted for $98 \%$ of rotavirus gastroenteritis cases in the study areas, while the remaining $2 \%$ of rotavirus gastroenteritis cases were due to the G6, G8, G10 and G12 genotypes (Van Damme et al., 2017).

We found a significant relationship between certain genotypes and clinical manifestations, including dehydration signs, febrile temperature, vomiting and diarrhea. G1P[8] was significantly associated with vomiting episodes compared to other genotypes. In our study the G1P[8] genotype had statistically significant positive correlation with chronic diseases. Interestingly, we found a significant association between G8P[8] genotype and dehydration signs, febrile temperature or vomiting episodes. Shim et al. (2016) found that G2P[4] was significantly associated with greater vomiting-related severity compared to other genotypes, including G1P[8]. However, the association between G2P[4] and clinical severity itself is mostly consistent with the results of several studies from the pre-vaccine era (Bern et al., 1992; Cascio et al., 2001).

Genotyping results were significantly associated with the severity of diarrhea using Vesikari symptom scores. In this study, the G3P[8] genotype had statistically significant positive correlation with durations of diarrhea and statistically significant negative correlation with vomiting and febrile temperature episodes. Multivariate analyses have identified that G3, G4 and G9 are correlated significantly with severe diarrhea and frequent diarrhea (Sudarmo et al., 2015).

\section{CONCLUSIONS}

In the study, we detected nine different rotavirus G genotypes, two different $\mathrm{P}$ genotypes and G4P[8], G9P[8], $\mathrm{G} 2 \mathrm{P}[8]$ were found to be the predominant genotypes. We determined correlation between the dominant genotypes and clinical manifestations of rotavirus gastroenteritis in our region.
This manuscript is part of the doctoral dissertation by the corresponding author Gunta Laizāne.

\section{ACKNOWLEDGEMENTS}

Project was granted by Rīga Stradiņš University (Grant No. RSU ZP 06/2013/2-3/155), and included in State Research Programme "Biomedicine", Project No. 5.6.2. "Research on acute and chronic diseases in a wide age range children to develop diagnostic and therapeutic algorithms to reduce mortality, prolong survival and improve quality of life".

We express our profound gratitude to Rīga Stradiņ̌ University for granting the project "Clinical peculiarities of Rota viral infection, molecular epidemiology and health-associated life quality for hospitalized children and their family members". We are also grateful to Dr. Marita Cikovska, Dr. Ieva Nokalna and Dr. Katrīna Selecka for their invaluable contributions to the project.

\section{REFERENCES}

Aly, M. Al Khairy, A., Al Johani, S., Balkhy, H. (2015). Unusal rotavirus genotypes among children with acute diarrhea in Saudi Arabia. BMC Infect. Dis., 15, 192

Anonymous (2011). Vesikari PATH, Clinical Severity Scoring System Manual Version. Available from: https://path.azureedge.net/media/docmuents/ VAD_vesikari_scoring_manual.pdf (accessed 15.05.2019).

Anonymous (2019). The Center for Disease Prevention and Control of Latvia. Available from: https://www.spkc.gov.lv/en (accessed 15.05.2019).

Bern, C., Unicomb, L., Gentsch, J. R., Banul, N., Yunus, M., Sack, R. B., et al. (1992). Rotavirus diarrhea in Bangladeshi children: Correlation of disease severity with serotypes. J. Clin. Microbiol., 30, 3234-3248.

Buttery, J. P., Lambert, S. B., Grimwood, K., Nissen, M. D., Field, E. J., Macartney, K. K., Akikusa, J. D., Kelly, J. J., Kirkwood, C. D. (2011). Reduction in rotavirus-associated acute gastroenteritis following introduction of rotavirus vaccine into Australia's National Childhood vaccine schedule. Pediatr. Infect. Dis. J., 30, S25-S29.

Cascio, A., Vizzi, E., Alaimo, C., Arista, S. (2001). Rotavirus gastroenteritis in Italian children: Can severity of symptoms be related to the infecting virus? Clin. Infect. Dis., 32, 1126-1132.

Cortese, M. M., Tate, J. E., Simonsen, L., Edelman, L., Parashar, U. D. (2010). Reduction in gastroenteritis in United States children and correlation with early rotavirus vaccine uptake from national medical claims databases. Pediatr. Infect. Dis. J., 29, 489-494.

Curns, A. T., Steiner, C. A., Barrett, M., Hunter, K., Wilson, E., Parashar, U. D. (2010). Reduction in acute gastroenteritis hospitalizations among US children after introduction of rotavirus vaccine: analysis of hospital discharge data from 18 US states. J. Infect. Dis., 201, 1617-1624.

Estes, M. K. (1996). Rotaviruses and their replication. In: Fields Virology. Fields, B. N. et al. (eds.). Lippincott Raven, Philadelphia, PA, 1625-1655.

Estes, M. K., Cohen, J. (1989). Rotavirus gene structure and functions. Microbiol. Rev., 53, 410-449.

Gentsch, J. R., Woods, P. A., Ramachandran, M., Das, B. K., Leite, J. P., Alfieri, A., Kumar, R., Bhan, M. K., Glass, R. I. (1996). Review of G and P typing results from a global collection of rotavirus strains: Implications for vaccine development. J. Infect. Dis., 174 (Suppl 1), S30-S36.

Gimenez-Sanchez, F., Delgado-Rubio, A., Martinon-Torres, F., BernaolaIturbe, E., Rotascore Research Group. (2010). Multicenter prospective study analysing the role of rotavirus on acute gastroenteritis in Spain. Acta Paediatr., 99, 738-742. 
Gouvea, V., Glass, R. I., Woods, P., Taniguchi, K., Clark, H. F., Forrester, B., et al. (1990). Polymerase chain reaction amplification and typing of rota virus nucleic acid from stool specimens. J. Clin. Microbiol., 28, 276-282.

Ianiro, G., Delogu, R., Fiore, L., Monini, M., Ruggeri, F. M.; RotaNet-Italy Study Group. (2017). Group A rotavirus genotypes in hospital-acquired gastroenteritis in Italy, 2012-14. J. Hosp. Infect., 96 (3), 262-267.

Parashar, U. D., Burton, A., Lanata, C., Boschi-Pinto, C., Shibuya, K., Steele, D., Birmingham, M., Glass, R. I. (2009). Global mortality associated with rotavirus disease among children in 2004. J. Infect. Dis., 200 (Suppl 1), S9-S15.

Piekarska, A., Kacerka, A., Majda-Stanisławska, E., Jóźwiak, B., Sidorkiewicz, M. (2015). Predominance of genotype P[9]G3 in rotavirus gastroenteritis in Polish children. Arch. Med. Sci., 11 (3), 577-583.

Seo, J. K., Sim, J. G. (2000). Overview of rotavirus infections in Korea. Pediatr. Int., 42, 406-410.
Shim, J. O., Chang, J. Y., Shin, S., Moon, J. S., Ko, J. S. (2016). Changing distribution of age, clinical severity, and genotypes of rotavirus gastroenteritis in hospitalized children after the introduction of vaccination: A single center study in Seoul between 2011 and 2014. BMC Infect. Dis., 16, 287.

Soeorg, H., Tamm, E., Huik, K., Pauskar, M. et al. (2012). Group A rotavirus genotypes circulating prior to implementation of a National Immunization Program in Estonia. Hum. Vaccin. Immunother., 8 (4), 465-469.

Sudarmo, S. M., Shigemura, K., Athiyyah, A. F. et al. (2015). Genotyping and clinical factors in pediatric diarrhea caused by rotaviruses: One-year surveillance in Surabaya, Indonesia. Gut Pathog., 7, 3.

Ushijima, H., Shinozaki, T., Fang, Z. Y., Glass, R. I. (1992). Group B rota virus antibody in Japanese children. J. Diarrhoeal Dis. Res., 10, 41.

Van Damme, P., Giaquinto, C., Maxwell, M., Todd, P., Van der Wielen, M., REVEAL Study Group. (2007). Distribution of rotavirus genotypes in Europe, 2004-2005: the REVEAL Study. J. Infect. Dis., 195 Suppl 1, S17-25.

Received 7 November 2018

Accepted in the final form 13 May 2019

\section{ROTAVĪRUSA KLĪNISKO ĪPATNĪBU UN GENOTIPU RAKSTUROJUMS BĒRNU KLĪNISKĀ UNIVERSITĀTES SLIMNĪCĀ STACIONĒTIEM BĒRNIEM}

Pētìjuma mērḳis bija izvērtēt rotavīrusa infekcijas galvenos cirkulējošos serotipus pirms imunizācijas ieviešanas Latvijā un noskaidrot to iespējamās korelācijas ar klīniskiem simptomiem. No 2013. gada aprị̣̄a līdz 2015. gada decembrim tika veikts šķērsgriezuma pētījums. Rotavīrusa genotipēšana tika veikta 462 feeču paraugiem. Bērniem līdz piecu gadu vecumam G/P kombinācijās dominējošie genotipi bija G4P[8] (61,3\%), G9P[8] (12,4\%) un G2P[4] (10,0\%), savukārt G4P [8] (45,5\%), G2P[4] (18,2\%), G9P[8], G3P[8] un G1P[8] (9,1\%) dominēja bērniem, kas vecāki par pieciem gadiem. Pētījumā tika konstatēta statistiski nozīmīga korelācija $(\mathrm{p}<0,05)$ starp klīniskajām pazīmēm (vemšana, dehidratācija, hroniskas slimības) un G1P[8], G8P[8] genotipiem. Zīdainiem ar genotipu G4P[4] bija statistiski nozīmīga negatīva korelācija ar akūta gastroenterīta epizožu smagumu $(p<0,05)$. Mēs noteicām deviṇus dažādus rotavīrusa $\mathrm{G}$ genotipus, divus P genotipus. Mūsu pētītajā populācijā dominēja G4P[8], G9P[8], G2P[8] genotipi. 